\title{
Frost Hardiness of some Turkish Apricot Cultivars during the Bloom Period
}

\author{
Nurdan Tuna Gunes ${ }^{1}$ \\ Ankara University, Faculty of Agriculture, Department of Horticulture 06110 \\ Ankara, Turkey
}

Additional index words. apricot, Prunus armeniaca, frost hardiness, spring frost

\begin{abstract}
The frost hardiness of five apricot (Prunus armeniaca L.) cultivars used for drying and/or the fresh market was investigated under controlled conditions and in the orchard. The hardiness of flower buds at three different development stages, such as first white, first bloom, and full bloom, was tested at $-4^{\circ} \mathrm{C}$ for 1 hour and 3 hours in the laboratory. The flower buds of 'Kabaasi', 'Sekerpare', and 'Alyanak' were hardier. The field observations obtained from the apricot orchard where the late frost occurred at night on 3 to 4 Apr. 2004 supported this result, and the temperatures at frost date varied from -2 to $-9^{\circ} \mathrm{C}$.
\end{abstract}

Low temperatures during and after budbreak may limit the distribution of deciduous fruit trees and may also seriously impair fruit production caused by freezing injuries in areas where the particular crop is already well established (Rodrigo, 2000). The most significant damages occur in buds, flowers, developing fruits and also shoots (Smeeton, 1964). Furthermore, year-to-year variations in crop production traditionally related to weather conditions in the spring also cause major economic losses. While the main causes determining cold hardiness are not certain (Ashworth, 1986; Guy, 1990; Thomashow, 1998), some factors such as genotype, developmental stage, the formation of ice, moisture content, nutritive status of the pistil and even environmental factors have been mentioned in the resistance of flower buds to spring frosts. In addition, destructive critical temperatures vary on not only the phenological stage, but also vary among species, cultivars, orchards (Proebsting and Mills, 1978a), and even within the trees (Westwood, 1993).

Apricot (Prunus armeniaca L.), is one of the most important stone fruits grown in the world after peach and plum. The world apricot production is about 2,7 million tons (FAO, 2004), and Turkey is one of the leading producers especially in the drying market. Since Turkey supports about 80\% (71,900 t) of the world dried apricot export $(91,011 \mathrm{t})$ (FAO, 2003), there are a lot of cultivars having high soluble solids content suitable for drying in Turkey. The most known cultivar is 'Hacihaliloglu' (Layne et al., 1996).

The world dried apricot production and trade have been seriously affected and have dropped 2-fold in some year because of late spring frosts. It will be very beneficial to determine frost hardiness of cultivars especially suitable for drying in Turkey. As it is well known, apricot is susceptible to spring frost because of its early bloom period in the spring and structure of its flowers. So, spring frosts are the most important environmental factor limiting apricot yield in Turkey.

Received for publication 8 Nov. 2005. Accepted for publication 27 Dec. 2005.

${ }^{1}$ Corresponding author; e-mail tuna@agri.ankara. edu.tr.
Information about spring frost hardiness during the bloom period of apricot cultivars is limited. Some data on low temperature hardiness of apricot fruit buds has been focused on recently bred cultivars, but most of them are mainly on the critical winter temperatures (Layne, 1978, 1984, 1991; Mehlenbacher et al., 1987). Critical winter temperatures were reported as -3.9 and $-2.2{ }^{\circ} \mathrm{C}$ at the first white and full bloom development stages of flower buds, respectively, for the spring frosts (Rogers and Swift, 1970). This paper presents the spring frost hardiness of flower buds at three different developmental stages for five apricot cultivars used for drying and/or fresh eating.

\section{Plant Material}

The spring frost hardiness was determined in the flower buds of 'Hacihaliloglu', 'Cataloglu', suitable for drying, 'Sekerpare', 'Alyanak', suitable for the fresh market, and 'Kabaasi', suitable for drying and also fresh market. These cultivars were grafted on apricot seedling and were 5 years old when investigated in this research.

\section{Laboratory and Field Study}

Live flower buds at three developmental stages, first white, first bloom and full bloom (Proebsting and Mills, 1978a; Westwood, 1993) were randomly collected from all quadrants of the trees and were soon exposed to -4 ${ }^{\circ} \mathrm{C}$ temperature and $75 \%$ relative humidity in the dark for $1 \mathrm{~h}$ and $3 \mathrm{~h}$. Subsequently, they were transferred to ambient conditions at 20 ${ }^{\circ} \mathrm{C}$ for $24 \mathrm{~h}$, and were then evaluated carefully for cold hardiness. The hardiness determinations were carried out on pistils of the buds. Discolored pistils were classified as dead and results were calculated as per cent dead flowers after counting(Modlibowska, 1962; Proebsting and Mills, 1978a, 1978b). The experiments were based on a completely randomized design with three replications consisting of 30 buds per replication. The laboratory tests were repeated two times in Spring 2004 and mean values of these repetitions were used in the statistical analyses.

For the orchard observations, flower buds were randomly taken from all quadrants of trees a day after a critical orchard frost occurred on the night of 3 to 4 Apr. 2004. At that time, the temperatures were recorded between -2 and $-9{ }^{\circ} \mathrm{C}$ in the orchard at the Experiment and Research Farm of Ankara University, Faculty of Agriculture (Turkey) (39 $36^{\prime} \mathrm{N}, 32^{\circ} 40^{\prime}$ E, $1600 \mathrm{~m}$ in elevation) (Table 1). Actually, spring frost in this orchard occurred rarely and generally apricot trees had regularly optimum yield. The flower hardiness of those same five cultivars was determined based on the method described above (Modlibowska, 1962; Proebsting and Mills, 1978a, 1978b) on sixty flower buds, arranged as three replications.

Multifactorial variance analysis (ANOVA) was performed on the data by Minitab software (MINITAB Inc.). Cultivar, developmental stage and cold treatment were taken into consideration as variables. Means were compared by Duncan's multiple range test $(P \leq$ $0.05)$. Arcsin transformations were used for all percentage data.

\section{Results}

In the laboratory tests, killing rates ranged from $2.1 \%$ in the flower buds of 'Alyanak' cultivar at full bloom stage and in cold treatment of $1 \mathrm{~h}$ to $49.1 \%$ in 'Hacihaliloglu' at first bloom stage and for $3 \mathrm{~h}$ cold treatment (Table $2)$. The effects of cultivar $\times$ developmental stage $\times$ cold treatment time $(P=0.061)$ on the killing rate of the cultivars was not significant $(P \leq 0.05)$ but two-way interactions such as cultivar $\times$ cold treatment time $(P=$ $0.001)$ and cultivar $\times$ developmental stage $(P$ $=0.000)$ were significant with the exception of developmental stage $\times$ cold treatment time $(P=0.098)$. In the first white developmental stage, the lowest killing rates were recorded in 'Kabaasi', 'Alyanak' and 'Sekerpare' as 4.8\%, $10.4 \%, 10.6 \%$, respectively. The flower buds of 'Cataloglu' significantly damaged $(P \leq 0.05)$. In the first bloom stage, the buds of 'Kabaasi' and 'Sekerpare' were significantly hardiest with killing ratios of $6.6 \%$ and $8.6 \%$, respectively (Table 2). 'Alyanak' followed numerically, it was not significantly different from 'Sekerpare'. The most frost sensitive cultivars were 'Hacihaliloglu' and 'Cataloglu' in this stage $(P \leq 0.05)$. In the full bloom developmental stage, while the flower buds of 'Alyanak' and 'Kabaasi' were hardiest with killing levels of $10.1 \%$ and $10.9 \%$, 'Sekerpare' was the third numerically, but it did not differ significantly from 'Kabaasi' $(P \leq 0.05)$. In this stage, it was observed that the flower buds of 'Cataloglu' were the most sensitive within all cultivars $(P \leq 0.05)$. When the cold hardiness in flower buds of each cultivar by progressing of the developmental stages was considered, it was possible to see that changing of hardiness was clearer for the flower buds of 'Hacihaliloglu' rather than the others. In this cultivar, the flower buds were satisfactorily resistant to cold especially at first white and full bloom developmental stages $(P \leq 0.05)$. However, similar clear differences were not observed for the flower buds of the other cultivars.

Based on the average values obtained in this 
Table 1. Temperature and relative humidity in orchard on 3 and 4 Apr. 2004.

\begin{tabular}{|c|c|c|c|c|c|c|c|c|c|c|c|c|c|}
\hline Hours & 21 & 22 & 23 & 24 & 1 & 2 & 3 & 4 & 5 & 6 & 7 & 8 & 9 \\
\hline Temperature $\left({ }^{\circ} \mathrm{C}\right)$ & 4 & 0 & -2 & -3 & -4 & -5 & -6 & -6 & -8 & -8 & -7 & -9 & -2 \\
\hline
\end{tabular}

study, the flower buds of 'Kabaasi', 'Alyanak' and 'Sekerpare' had the lowest damages as $5.2 \%, 5.8 \%$, and $6.2 \%$ killing rate at the end of an hour cold treatment at $-4{ }^{\circ} \mathrm{C}$, respectively $(P \leq 0.05)$. This treatment caused statistically highest killing levels in the other two cultivars, 'Cataloglu' and 'Hacihaliloglu', In cold treatment of 3 h, 'Kabaasi' showed the lowest killing rate as $9.6 \%$ and the other cultivars were enumerated as 'Alyanak', 'Sekerpare', 'Hacihaliloglu', 'Cataloglu' $(P \leq 0.05)$. Furthermore, killing rates of the flower buds changed based on the time in cold but significant differences between the times were observed for the flower buds of only 'Alyanak' and 'Sekerpare' cultivars. In these cultivars, killing rates increased from $5.8 \%$ to $17.1 \%$ and from $6.2 \%$ to $17.2 \%$, respectively, depending on longevity of the cold treatment $(P \leq 0.05)$.

As it can be followed from Table 3, it was observed that there were together effects of cultivar and developmental stage on the killing rate of the flower buds $(P \leq 0.05)$ after the frost occurred in the orchard. The most hardiness cultivars in the field were 'Kabaasi', and 'Sekerpare' with killing rates of $20.9 \%$ and $30.6 \%$, respectively, at the first white stage. In the last two developmental stages, the flower buds of 'Sekerpare' were the hardiest, but buds of 'Kabaasi' were moderately hardy similar to 'Alyanak' $(P \leq 0.05)$. The most sensitive buds were of 'Hacihaliloglu' and 'Cataloglu'. Especially in these cultivars, frost injury reached up to $100 \%$ at the full bloom stage. It was observed after the orchard frost that freezing injury increased by advancing of the development in all cultivars with the exception of 'Sekerpare' $(P \leq 0.05)$. The bud damages ranged between $11.5 \%$ and $20.9 \%$ in this cultivar.

\section{Discussion}

For the flower buds of apricot, the critical temperatures were reported as $-3.9^{\circ} \mathrm{C}$ for the first white and as $-2.2{ }^{\circ} \mathrm{C}$ for the full bloom stage (Rogers and Swift, 1970). In addition, Proebsting and Mills (1978a) determined the average $T_{10}$ values for the first white, first bloom and full bloom stages of several apricot cultivars as $-4.9,-4.3$, and $-2.9^{\circ} \mathrm{C}$, respectively. But $\mathrm{T}_{50}$ values were much lower than these temperatures. In the current study, temperature of $-4{ }^{\circ} \mathrm{C}$ for an hour was enough for $>10 \%$ killing of the flower buds in 'Hacihaliloglu' and 'Cataloglu' cultivars for all of the developmental stage (Table 2). But, all cultivars had more than $10 \%$ killing rates at the end of $3 \mathrm{~h}$ at $-4^{\circ} \mathrm{C}$ with the exception of 'Kabaasi' at the first white and 'Kabasi' and 'Sekerpare' at the first bloom developmental stages.

As mentioned in other studies on the hardiness of the flower buds in fruit crops (Proebsting and Mills, 1978a; Quamme, 1983; Rodrigo, 2000; Westwood, 1993), there was large variability observed among cultivars and development stage of buds for the different cold durations in the current study (Table 2). For all developmental stages, the flower buds of 'Kabaasi', 'Sekerpare', and 'Alyanak' cultivars seemed to be significantly hardier than the other two cultivars under controlled conditions, based on the average values ( $P$ $\leq 0.05)$. This situation was also proved with field observations (Table 3). However, Ozturk et al. (2001) determined 'Kabaasi', 'Soganci', and 'Hacihaliloglu' cultivars as the hardiest at the pink cluster (at $-4{ }^{\circ} \mathrm{C}$ ), full bloom (at -1 ${ }^{\circ} \mathrm{C}$ ) and post bloom $\left(\right.$ at $-1{ }^{\circ} \mathrm{C}$ ) developmental stages for $2 \mathrm{~h}$ under controlled conditions. These results are not in complete agreement with the current study, because 'Hacihaliloglu' was one of the most cold sensitive cultivars in this study. Additionally, the frost hardiness did not satisfactorily change in all cultivars based on the developmental stages, with the excep- tion of 'Hacihaliloglu' and the flower buds of this cultivar were significantly hardier at the first white and the full bloom developmental stage based on the results of the laboratory tests $(P \leq 0.05)$.

The freezing injury increases in fruit species depending on time exposed to cold (Strang et al., 1980; Westwood, 1993). In the current study, this was corroborated for 'Alyanak' and 'Sekerpare' cultivars under controlled conditions $(P \leq 0.05)$ (Table 2$)$. This might depend upon the differences among supercooling points of the cultivars (Quamme, 1983).

In many studies it was reported that hardiness was rapidly lost and lethal threshold temperature increased by the progression of bud development in deciduous fruit species (Andrews et al., 1983; Proebsting and Mills, 1978a; Simons and Doll, 1976; Westwood, 1993). As shown in Table 3, the results of this

Table 2. The percentage of killed flower buds after controlled freezing test at $-4{ }^{\circ} \mathrm{C}$.

\begin{tabular}{|c|c|c|}
\hline Effects & Killed flower buds (\%) & $P$ \\
\hline \multicolumn{3}{|l|}{ Cultivar } \\
\hline \multicolumn{3}{|l|}{ Alyanak } \\
\hline \multicolumn{3}{|l|}{ Cataloglu } \\
\hline \multicolumn{3}{|l|}{ Hacihaliloglu } \\
\hline \multicolumn{3}{|l|}{ Kabaasi } \\
\hline \multicolumn{3}{|l|}{ Sekerpare } \\
\hline \multicolumn{3}{|l|}{ Developmental stage } \\
\hline \multicolumn{3}{|l|}{ First white } \\
\hline \multicolumn{3}{|l|}{ First bloom } \\
\hline \multicolumn{3}{|l|}{ Full bloom } \\
\hline \multicolumn{3}{|l|}{ Treatment time } \\
\hline \multicolumn{3}{|l|}{$1 \mathrm{~h}$} \\
\hline \multicolumn{3}{|l|}{$3 \mathrm{~h}$} \\
\hline \multicolumn{3}{|l|}{ Significant interaction effects } \\
\hline Cultivar $\times$ developmental stage & & 0,000 \\
\hline Alyanak $\times$ first white & $10.4 \mathrm{c}, \mathrm{A}^{\mathrm{z}}$ & \\
\hline Alyanak $\times$ first bloom & $13.8 \mathrm{~b}, \mathrm{~A}$ & \\
\hline Alyanak $\times$ full bloom & $10.1 \mathrm{~d}, \mathrm{~A}$ & \\
\hline Cataloglu $\times$ first white & $28.9 \mathrm{a}, \mathrm{A}$ & \\
\hline Cataloglu $\times$ first bloom & $36.6 \mathrm{a}, \mathrm{A}$ & \\
\hline Cataloglu $\times$ full bloom & $38.9 \mathrm{a}, \mathrm{A}$ & \\
\hline Hacihaliloglu $\times$ first white & $18.9 \mathrm{~b}, \mathrm{~B}$ & \\
\hline Hacihaliloglu $\times$ first bloom & $45.5 \mathrm{a}, \mathrm{A}$ & \\
\hline Hacihaliloglu $\times$ full bloom & $21.7 \mathrm{~b}, \mathrm{~B}$ & \\
\hline Kabaasi $\times$ first White & $4.8 \mathrm{c}, \mathrm{A}$ & \\
\hline Kabaasi $\times$ first Bloom & $6.6 \mathrm{c}, \mathrm{A}$ & \\
\hline Kabaasi × full Bloom & $10.9 \mathrm{~cd}, \mathrm{~A}$ & \\
\hline Sekerpare $\times$ first white & $10.6 \mathrm{c}, \mathrm{A}$ & \\
\hline Sekerpare $\times$ first bloom & $8.6 \mathrm{bc}, \mathrm{A}$ & \\
\hline Sekerpare $\times$ full bloom & $15.9 \mathrm{bc}, \mathrm{A}$ & \\
\hline Cultivar $\times$ treatment time & & 0,001 \\
\hline Alyanak $\times 1 \mathrm{~h}$ & $5.8 \mathrm{~b}, \mathrm{~B}^{\mathrm{y}}$ & \\
\hline Alyanak × $3 \mathrm{~h}$ & $17.1 \mathrm{~b}, \mathrm{~A}$ & \\
\hline Cataloglu $\times 1 \mathrm{~h}$ & $35.7 \mathrm{a}, \mathrm{A}$ & \\
\hline Cataloglu $\times 3 \mathrm{~h}$ & $33.9 \mathrm{a}, \mathrm{A}$ & \\
\hline Hacihaliloglu $\times 1 \mathrm{~h}$ & $28.5 \mathrm{a}, \mathrm{A}$ & \\
\hline Hacihaliloglu $\times 3 \mathrm{~h}$ & $28.9 \mathrm{a}, \mathrm{A}$ & \\
\hline Kabaasi $\times 1 \mathrm{~h}$ & $5.2 \mathrm{~b}, \mathrm{~A}$ & \\
\hline Kabaasi $\times 3 \mathrm{~h}$ & $9.6 \mathrm{~g}, \mathrm{~b}, \mathrm{c} \mathrm{A}$ & \\
\hline Sekerpare $\times 1 \mathrm{~h}$ & $6.2 \mathrm{~b}, \mathrm{~B}$ & \\
\hline Sekerpare $\times 3 \mathrm{~h}$ & $17.2 \mathrm{~b}, \mathrm{~A}$ & \\
\hline
\end{tabular}

${ }^{{ }^{z}}$ Lower case letters show differences among cultivars in each developmental stage, capital letters show differences among developmental stages for each cultivar, at $P \leq 0.05$ error level according to Duncan's multiple range test.

${ }^{y}$ Lower case letters show differences among cultivars for each treatment time, capital letters show differences between cold treatment times for each cultivar, at $P \leq 0.05$ error level according to Duncan's multiple range test. 
Table 3. The percentage of killed flower buds in orchard after spring frost.

\begin{tabular}{lcc}
\hline Effects & Killed flower buds (\%) & $P$ \\
\hline Main effects & & 0,000 \\
Cultivar & & \\
Alyanak & & \\
Cataloglu & & \\
Hacihaliloglu & & \\
Kabaasi & & \\
Sekerpare & & \\
Developmental stage & & \\
First white & & \\
First bloom & & \\
Full bloom & $52 \mathrm{~b}, \mathrm{~B}$, & \\
Significant interaction effects & $64.5 \mathrm{~b}, \mathrm{~B}$ & \\
Cultivar $\times$ developmental stage & $78 \mathrm{~b} \mathrm{~A}$ & \\
Alyanak $\times$ first white & $79.8 \mathrm{a}, \mathrm{B}$ & \\
Alyanak $\times$ first bloom & $98.1 \mathrm{a}, \mathrm{A}$ & \\
Alyanak $\times$ full bloom & $100 \mathrm{a}, \mathrm{A}$ & \\
Cataloglu $\times$ first white & $84.4 \mathrm{a}, \mathrm{B}$ & \\
Cataloglu $\times$ first bloom & $99.4 \mathrm{a}, \mathrm{A}$ & \\
Cataloglu $\times$ full bloom & $100 \mathrm{a}, \mathrm{A}$ & \\
Hacihaliloglu $\times$ first white & $30.6 \mathrm{c}, \mathrm{C}$ & \\
Hacihaliloglu $\times$ first bloom & $57.5 \mathrm{~b}, \mathrm{~B}$ & \\
Hacihaliloglu $\times$ full bloom & $76.4 \mathrm{~b}, \mathrm{~A}$ & \\
Kabaasi $\times$ first white & $20.9 \mathrm{c}, \mathrm{A}$ & \\
Kabaasi $\times$ first bloom & $11.5 \mathrm{c}, \mathrm{A}$ & \\
Kabaasi $\times$ full bloom & $15.8 \mathrm{c}, \mathrm{A}$ & \\
Sekerpare $\times$ first White & & \\
Sekerpare $\times$ first bloom & & \\
Sekerpare $\times$ full bloom & & \\
\hline & & \\
\hline
\end{tabular}

${ }^{2}$ Lower case letters show differences among cultivars in each developmental stage, capital letters show differences among developmental stages for each cultivar, at $P \leq 0.05$ error level according to Duncan's multiple range test.

study indicated that the level of frost injury increased in all cultivars, with the exception of 'Sekerpare' by advancement of bud development in the orchard.

As a result of the current research, the flower buds of 'Kabaasi', 'Sekerpare', and 'Alyanak' were significantly hardier than the buds of 'Hacihaliloglu' and 'Cataloglu' under uniform conditions. Since spring frost hardiness in flower buds depends a lot on factors such as physiological and environmental, it might be very beneficial to determine the main reasons for increased hardiness in these cultivars, especially for future apricot breeding studies.
Layne, R.E.C. 1984. 'Harglow' apricot. HortScience 19:136-137.

Layne, R.E.C. 1991. 'Harval' apricot. HortScience $26: 424-425$

Layne, R.E.C., C.H. Bailey, and L.F. Hough. 1996. Apricots, p. 79-111. In: J. Janick and J.N. Moore (eds.). Fruit breeding. vol. 1. Tree and tropical fruits. John Wiley and Sons, Inc., New York.

Mehlenbacher, S.A., L.F. Hough, and A. Voordeckers. 1987. 'Jersey' apricot. HortScience 22:680-681.

Modlibowska, I. 1962. Some factors affecting supercooling of fruit blossoms. J. Hort. Sci. 37:249-261.

Ozturk, K., A.B. Kuden, H.A. Olmez, and U. Guloglu. 2001. Studies on the effect of frost duration on some dried apricot cultivars grown in Malatya province to winter and spring frosts, p. 491-499. In: M.E. Ergun and M. Burak (eds.). Proc. 1st National Stone Fruits Symp., Yalova, Turkey.

Proebsting, Jr., E.L. and H.H. Mills. 1978a. Low temperature resistance of developing flower buds of six deciduous fruit species. J. Amer. Soc. Hort. Sci. 103:192-198.

Proebsting, Jr., E.L. and H.H. Mills. 1978b. A synoptic analysis of peach and cherry flower bud hardiness. J. Amer. Soc. Hort. Sci. 103:842-845.

Quamme,H.A. 1983. Relationship of air temperature to water content and supercooling of overwintering peach flower buds. J. Amer. Soc. Hort. Sci. 108:697-701.

Rodrigo, J. 2000. Spring frosts in deciduous fruit trees-morphological damage and flower hardiness. Scientia Hort. 85:155-173.

Rogers, W.J. and H.L. Swift. 1970. Frost and the prevention of frost damage. U.S. Dept. Commerce NOAA, Silver Spring Md.

Simons, R.K. and C.C. Doll. 1976. Morphological and anatomical response of apples to a late spring frost in relation to stage of fruit development. J. Amer. Soc. Hort. Sci. 101:315-320.

Smeeton, R. 1964. Late spring frost damage to apple shoots in the nursery. Rpt. E Malling Res. Sta. For. 1963 A47:7-74.

Strang, J.G., P.B. Lombard, M.N. Westwood, C.J. Weiser. 1980. Effect of duration and rate of freezing and tissue hydration of Bartlett pear buds, flowers, and small fruits. Amer. Soc. Hort. Sci. 105:102-107.

Thomashow, M.F. 1998. Role of cold-responsive genes in plant freezing tolerance. Plant Physiol. 118:1-7.

Westwood, M.N. 1993. Temperate-zone pomology: Physiology and culture. Timber Press, Portland, Ore. 